\title{
Evaluation of Antidiarheal and Antidiabetic Activities of Wrigthia arborea (Dennst.) Mabb.
}

\author{
Ronok Zahan', Laizuman Nahar', Zahangir Alam², Mst. Luthfun Nesa² \\ and M. Ekramul Haque ${ }^{1}$ \\ ${ }^{1}$ Department of Pharmacy, Rajshahi University, Rajshahi-6205, Bangladesh. \\ ${ }^{2}$ Department of Pharmacy, Atish Dipankar University of Science \& Technology, Banani, Dhaka-1213, Bangladesh.
}

\begin{abstract}
Wrigthia arborea (Dennst.) Mabb., locally known as Shet-kurchi, is a small deciduous tree. These species are important in the traditional healthcare, especially in menstrual and renal complaints. The present study was designed to investigate the antidiarheal and antidiabetic activities of methanol extract of $W$. arborea. The methanol extract was studied for antidiarrhoeal properties using castor oil and magnesium sulphate induced diarrhoeal model in mice. At the doses of 100 and $200 \mathrm{mg} / \mathrm{kg}$ body weight, the extract reduced the frequency and severity of diarrhea in test animals throughout the study period. Antidiabetic effect was also evaluated in normal and alloxan induced diabetic rats. Considerable drop of elevated blood glucose level was observed in the normoglycemic and alloxan induced diabetic rats at a dose of 150 and $300 \mathrm{mg} / \mathrm{kg} \mathrm{b.w.} \mathrm{when} \mathrm{the} \mathrm{extract} \mathrm{was} \mathrm{given}$ intraperitoneally. Altogether, these results suggest that the methanol extract could be used for treating diarrhea and diabetes. This is the first report of antidiarheal and antidiabetic potential of $W$. arborea.
\end{abstract}

Key words: Wrigthia arborea, antidiarrhoeal, alloxan, antidiabetic.

\section{Introduction}

Plants are rich in a wide variety of secondary metabolites such as tannins, terpenoids, alkaloids, flavonoids, etc. which showed wide range of in vitro antibacterial and antifungal activities (Dahanukar et al., 2000; Cowan, 1999). The incidence of food-borne illnesses is still a major problem, even in developed countries. It has been estimated that 6-81 million cases of illnesses and up to 9000 deaths annually were attributed to food-borne pathogens in the USA alone (Meads et al., 1999). Diarrhoea is a major problem in Bangladesh. Every year many people suffer from this disease. Antibiotics and gut motility suppressing agents are usually used to reverse dehydration, shorten the length of illness and reduce the period of diarrhea (Allen et al., 2003). Treatment with pharmacological agents that are pathogenspecific or that suppress severe symptoms would be of beneficial in this regard (Takahashi et al., 2001; Oi et al., 2002). On the other hand, diabetes mellitus is one of the common metabolic disorders. Almost $1.3 \%$ of the population suffers from this disease throughout the world (Ghosh et al., 2004). Insulin therapy is the only satisfactory approach in diabetic mellitus, even though it has several drawbacks like insulin resistance (Piedrola et al., 20011), anorexia, brain atrophy and fatty liver in chronic treatment (Pari and Uma, 1999). Hence, the search for safer and more effective hypoglycemic agents is essential.

Wrightia is a genus of 23 species of flowering plants in the Apocynaceae (dogbane) family, native to tropical Africa, Asia and Australia (Nagan, 1965). W. arborea is a small deciduous tree with small branches and densely velvety leaves. Bark is gray, thick and corky and flowers are pale yellow with a fleshy orange-colored corona of scales at the center. Fruits abd pods are joined together and cylindrical (FlowersofIndia.net, 2009). It is locally known as Shet-kurchi (Chittagong, Bangladesh). These species have been found important in the traditional healing. Leaves are used in toothache and fever. Roots are also used in fever. The latex of the plant is used to stop haemorrhage. Bark is antidysenteric and also useful in menstrual and renal complaints. An isoflavone, wrightiadione, has been isolated from this plant, which displays cytotoxic activity against leukaemia cells. It also 
contains the amoebicidal steroidal alkaloids such as conessine, conessidine, kurchine, kurchicine, conkurchine and holarrhine. Strophanthus acid (9-hydroxy-cis-12octadecanoic acid) occurs as the major component of the seed fat (Mpbd.info, 2009).

As the comprehensive phytochemical and biological studies have not been carried out with the $W$. arborea, the present study was designed to evaluate the antidiarheal and antidiabetic activities of methanol extract of the leaf of W. arborea.

\section{Materials and Methods}

Plant material: The leaf of the $W$. arborea were collected from Banderban Hill Tracts, Chittagong, Bangladesh during February 2010 and were identified by Taxonomist Md. Boctiar Uddin, Associate Professor, Department of Botany, University of Chittagong, Bangladesh where a voucher specimen number (Voucher No-147) has been deposited.

Chemicals: The active drugs metformin and loperamide were the generous gift samples from Square Pharmaceuticals Ltd., Bangladesh. Castrol oil and alloxan were obtained from Merck, Germany. Normal saline solution was purchased from Beximco Infusion Ltd., Bangladesh. All chemicals used were of analytical reagent grade.

Preparation of extract: The air dried and powdered plant material (700 g) was extracted in a Soxhlet apparatus with methanol. The extract was filtered through a fresh cotton plug followed by Whatman no.1 filter paper. The filtrate was then concentrated with a Buchii rotavapor at low temperature and pressure to afford methanol extract (120 g approx.).

Animal: Swiss albino mice (25-30g) and Young Long-Evans rats of either sex weighing about 80-120g were used for assessing the biological activities. The animals were maintained under standard laboratory conditions and had free access to food and water ad libitum. The animals were allowed to acclimatize to the environment for 7 days prior to experimental session. The animals were divided into different groups, each consisting of five animals which were fasted overnight prior to the experiments. Experiments with the animals were performed in accordance with guidelines of the
Institutional Animal Ethics Committee, Department of Pharmacy, Rajshahi University, Bangladesh.

Acute toxicity: The acute oral toxicity of the plant extract in Swiss albino mice was studied as per established protocol (Lorke, 1983).

\section{In vivo antidiarrheal activity}

Castor oil-induced diarrhea: The experiment was performed according to the method described by Nahar et al., (2010). Briefly, mice fasted for $24 \mathrm{~h}$ were randomly allocated to four groups of six animals each. The animals were all screened initially by giving $0.5 \mathrm{ml}$ of castor oil. Only those showing diarrhea were selected for the final experiment. Group I received 1\% Tween 80 in water (10 $\mathrm{ml} / \mathrm{kg}$, p.o.), groups III and IV received the methanol extract (100 and $200 \mathrm{mg} / \mathrm{kg}$ ) whereas Group II was given antidiarrheal drug loperamide $(10 \mathrm{mg} / \mathrm{kg}$, p.o. $)$ in suspension form. After $60 \mathrm{~min}$, each animal was given 0.5 $\mathrm{ml}$ of castor oil \& placed in an individual cage, the floor of which was lined with blotting paper which was changed every hour, observed for $4 \mathrm{hr}$ and the characteristic diarrheal droppings were recorded.

Magnesium sulphate-induced diarrhea: Diarrhea was induced by oral administration of magnesium sulfate at the dose of $2 \mathrm{~g} / \mathrm{kg}$ to the animals $30 \mathrm{~min}$ after pre-treatment with vehicle ( $1 \%$ Tween 80 in water, $10 \mathrm{ml} / \mathrm{kg}$, p.o.) to the control group, loperamide $(10 \mathrm{mg} / \mathrm{kg}$ ) to the positive control group, and the methanol extract at the doses of 100 and $200 \mathrm{mg} / \mathrm{kg}$ body weight to the test groups (Zahan et al., 2012a).

Antidiabetic activity test: The experiment was designed by the following published method (Nahar et al., 2010a). Animals were alienated into five groups and for every group six animals were taken.

Group I (Normal control) rats served as positive control and received physiological saline $(0.9 \% \mathrm{NaCl}$; $5 \mathrm{ml} /$ kg. b.w., p.o.).

Group II (Diabetic control) Alloxan induced diabetic rats treated by intraperitoneal injection of normal saline.

Group III rats were administered metformin hydrochloride ( $50 \mathrm{mg} / \mathrm{kg} /$ day) at a period of $24 \mathrm{hr}$ for 7 successive days and served as standard.

Group IV and V rats were received intraperitoneal injection of W. arborea (150 and 300mg/kg/day) for $24 \mathrm{hr}$ 
for three consecutive days. Blood glucose was measured on $1^{\text {st }}, 2^{\text {nd }}, 3^{\text {rd }}, 4^{\text {th }}, 5^{\text {th }}, 6^{\text {th }}$ and $7^{\text {th }}$ day.

Preparation of alloxan solution: At first body weight of rats were recorded. Then necessary amount of alloxan was measured for the dose at $110 \mathrm{mg}$ of alloxan per 1000 $\mathrm{g}$ of body weight and dissolved in $0.1 \mathrm{ml}$ of sterile normal saline water.

Induction of alloxan: The rats were injected alloxan monohydrate, dissolved in sterile normal saline water at a dose of $110 \mathrm{mg} / \mathrm{kg}$ body weight intraperitoneally once a day. After few days rats with moderate diabetes having glycosuria and hyperglycemia were chosen.

\section{Preparation of dosage of active drug and plant extract}

Metformin hydrochloride: Metformin hydrochloride was in microcrystalline form and freely soluble in water. The dosage was prepared in solution form with sterilized water in such a concentration that each $0.5 \mathrm{ml}$ contained metformin hydrochloride according to the dose of 50 $\mathrm{mg} / \mathrm{kg} /$ day.

W. arborea: The crude extract was dissolved in water to prepare the solution where each $0.1 \mathrm{ml}$ contained $W$. arborea according to the dose of 150 and $300 \mathrm{mg} / \mathrm{kg} / \mathrm{day}$. About $0.1 \mathrm{ml}$ of the test solution was administered everyday during treatment to achieve required dose of respective agents.

Biochemical assay: Fasting blood glucose level was evaluated in normal and diabetic rats from the tail vein by strip technique (Bioland Glucometer, Germany). At first it was done just prior to extract administration on the first day then it was continued for 7 days just one hour after the administration of plant extract.

Statistical analysis: All data are presented as mean \pm standard deviation (SD). Data were evaluated by one-way analysis of variance (ANOVA) using SPSS Version 15.0 (SPSS Inc., Chicago, IL, USA), and differences between means were assessed by Dunnett's $T$ test. The level of significance was set at $p<0.001$ for all statistical tests.

\section{Results}

The acute toxicity study was conducted to establish the therapeutic index, i.e., the ratio between the pharmacologically effective dose and the lethal dose on the same strain and species. The extract of $W$. arborea was safe up to a dose of $500 \mathrm{mg} / \mathrm{kg}$ (p.o.) body weight. The extract did not cause mortality in mice during $48 \mathrm{~h}$ of observation but little behavioral changes, locomotors ataxia, diarrhea and weight loss were observed. Food and water intake had no significant difference among the group studied.

In the castor oil induced diarrheal mice, the methanol extract of the leaf of $W$. arborea, at the dose of 100 and $200 \mathrm{mg} / \mathrm{kg}$, significantly $(p<0.001)$ reduced the total number of feces as well as delayed the onset of diarrhea in a dose dependent manner (Table 1).

$W$. arborea extract exhibited significant antidiarrheal activity against magnesium sulphate-induced diarrhea (Table 2). The extract at both dose levels significantly ( $p<$ 0.001 ) reduced the extent of diarrhea and also notably delayed the onset of diarrhea in a dose dependent manner.

Alloxan (110 mg/kg body wt.) administration resulted in significant elevation of glucose level. Administration of W. arborea at a dose of 150 and $300 \mathrm{mg} / \mathrm{kg}$ body weight administered for seven days were able to correct this aberration significantly ( $p<0.001)$. The results of all the formulations tested are presented in (Table 3).

Table 1. Effect of W. arborea methanol extract on castor oil-induced diarrhea in mice.

\begin{tabular}{lcccc}
\hline $\begin{array}{l}\text { Treatment } \\
\text { (Dose) }\end{array}$ & $\begin{array}{c}\text { Onset of diarrhea } \\
(\mathrm{min})\end{array}$ & $\begin{array}{c}\text { Animals with } \\
\text { diarrhea }\end{array}$ & No. of feces in $4 \mathrm{~h}$ & $\begin{array}{c}\text { \% inhibition of } \\
\text { defecation }\end{array}$ \\
\hline Vehicle control & $56.45 \pm 5.31$ & $5 / 5$ & $16.68 \pm 0.45$ & 93.52 \\
Loperamide $(10 \mathrm{mg} / \mathrm{kg})$ & $180.15 \pm 8.5^{* *}$ & $1 / 5$ & $3.27 \pm 0.21^{* *}$ & 36.15 \\
MEWA (100 mg/kg) & $90.28 \pm 5.40^{* *}$ & $2 / 5$ & $10.65 \pm 0.28^{* *}$ & 62.64 \\
MEWA (200 mg/kg) & $155.48 \pm 7.79^{* *}$ & $3 / 5$ & $6.23 \pm 0.25^{* *}$ & \\
\hline
\end{tabular}

Values are mean $\pm \operatorname{SEM}(\mathrm{n}=5) ;{ }^{* *} p<0.001$ by Dunnett’s T test for values between the sample and the vehicle treated group. 
Table 2. Effect of W. arborea methanol extract on magnesium sulphate-induced diarrhea in mice.

\begin{tabular}{lcccc}
\hline Treatment & $\begin{array}{c}\text { Onset of diarrhea } \\
(\mathrm{min})\end{array}$ & $\begin{array}{c}\text { Animals with } \\
\text { diarrhea }\end{array}$ & No. of feces in 4 h & $\begin{array}{c}\text { \% inhibition of } \\
\text { defecation }\end{array}$ \\
\hline Vehicle control & $48.42 \pm 4.5$ & $5 / 5$ & $8.45 \pm 0.07$ & 86.73 \\
Loperamide $(10 \mathrm{mg} / \mathrm{kg})$ & $160.54 \pm 6.5^{* *}$ & $1 / 5$ & $2.23 \pm 0.03^{* *}$ & 35.51 \\
MEWA $(100 \mathrm{mg} / \mathrm{kg})$ & $80.39 \pm 4.65^{* *}$ & $2 / 5$ & $6.12 \pm 0.07^{* *}$ & 69.51 \\
MEWA $(200 \mathrm{mg} / \mathrm{kg})$ & $137.46 \pm 5.25^{* *}$ & $3 / 5$ & $3.34 \pm 0.04^{* *}$ & \\
\hline
\end{tabular}

Values are mean $\pm \operatorname{SEM}(\mathrm{n}=5) ;{ }^{* *} p<0.001$ by Dunnett's $T$ test for values between the sample and the vehicle treated group.

Table 3. Oral glucose tolarence test after administration of $150 \mathrm{mg} / \mathrm{kg}$ and $300 \mathrm{mg} / \mathrm{kg}$ body wt. of extract on rat.

\begin{tabular}{lcccc}
\hline Groups & \multicolumn{3}{c}{ Blood glucose level (mmol/l) } \\
\cline { 2 - 4 } & Initial 0 min & $30 \mathrm{~min}$ & $60 \mathrm{~min}$ & $120 \mathrm{~min}$ \\
\hline Normal control & $5.33 \pm 0.10$ & $5.75 \pm 0.25$ & $5.28 \pm 0.27$ & $5.70 \pm 0.15$ \\
Diabetic Control & $5.01 \pm 0.22$ & $14.5 \pm 0.37$ & $15.3 \pm 0.39$ & $14.2 \pm 0.28$ \\
Met. HCl $50 \mathrm{mg} / \mathrm{kg}$ & $5.11 \pm 0.20$ & $7.9 \pm 0.11$ & $6.2 \pm 0.15$ & $5.45 \pm 0.19$ \\
MEWA $150 \mathrm{mg} / \mathrm{kg}$ & $5.53 \pm 0.19$ & $8.05 \pm 0.28^{* *}$ & $6.92 \pm 0.30^{* *}$ & $5.76 \pm 0.22^{* *}$ \\
MEWA. 300 mg/kg & $5.46 \pm 0.39$ & $6.14 \pm 0.26^{* *}$ & $6.18 \pm 0.30^{* *}$ & $5.38 \pm 0.28^{* *}$ \\
\hline
\end{tabular}

Values are mean $\pm \operatorname{SEM}(\mathrm{n}=5) ;{ }^{* *} p<0.001$ by Dunnett's $\mathrm{T}$ test for values between the sample and the diabetic control group.

Table 4. Effects of seven days treatment of methanol extract of $W$. arborea on blood sugar level of alloxan induced diabetic rat.

\begin{tabular}{|c|c|c|c|c|c|c|c|}
\hline \multirow[t]{2}{*}{ Groups } & \multicolumn{7}{|c|}{ Blood glucose level (mmol/l) } \\
\hline & $1^{\text {st }}$ Day & $2^{\text {nd }}$. Day & $3^{\text {rd }}$ Day & $4^{\text {th }}$. Day & $5^{\text {th }}$. Day & $6^{\text {th }}$ Day & $7^{\text {th }}$ Day \\
\hline Normal control & $5.10 \pm 0.17$ & $5.67 \pm 0.47$ & $4.98 \pm 0.13$ & $5.50 \pm 0.35$ & $5.0 \pm 0.26$ & $5.23 \pm 0.58$ & $5.47 \pm 0.53$ \\
\hline Diabetic control & $11.65 \pm 0.42$ & $14.23 \pm 0.31$ & $15.16 \pm 0.49$ & $16.54 \pm 0.32$ & $17.33 \pm 0.51$ & $17.72 \pm 1.05$ & $18.10 \pm 1.45$ \\
\hline Met. $\mathrm{HCl} 50 \mathrm{mg} / \mathrm{kg}$ & $12.46 \pm 0.67$ & $9.75 \pm 0.31^{* *}$ & $8.53 \pm 0.27^{* *}$ & $7.05 \pm 0.14^{* *}$ & $5.53 \pm 0.27^{* *}$ & $4.86 \pm 0.14^{* *}$ & $4.66 \pm 0.32^{* *}$ \\
\hline MEWA 150 mg/kg & $11.27 \pm 1.03$ & $10.01 \pm 1.29^{* *}$ & $8.93 \pm 0.72^{* *}$ & $8.01 \pm 0.41^{* *}$ & $7.2 \pm 0.43^{* *}$ & $6.56 \pm 0.63^{* *}$ & $6.01 \pm 0.57^{* *}$ \\
\hline MEWA 300 mg/kg & $11.01 \pm 0.72$ & $8.98 \pm 0.63^{* *}$ & $8.31 \pm 0.62^{* *}$ & $6.98 \pm 1.0^{* *}$ & $6.13 \pm 1.07^{* *}$ & $5.61 \pm 1.03^{* *}$ & $5.01 \pm 0.84^{* *}$ \\
\hline
\end{tabular}

Values are mean $\pm \operatorname{SEM}(\mathrm{n}=5) ;^{* *} p<0.001$ by Dunnett’s T test for values between the sample and the diabetic control group.

Before treatment schedule, fasting blood glucose level in all animals was within the normal range. After treatment with alloxan, the fasting blood glucose level was changed and it was significantly $(P<0.001)$ reduced after 7 days of treatment with methanol extract of $W$. arborea and this was comparable to the standard Metformin $\mathrm{HCl}$. On the progression of treatment with methanol extract of $W$. arborea (150 and $300 \mathrm{mg} / \mathrm{kg} /$ day) fasting blood glucose level reduced at $6.01 \pm 0.57 \mathrm{mmol} / \mathrm{L}$ and $5.01 \pm 0.84$ $\mathrm{mmol} / \mathrm{l}$, respectively on $7^{\text {th }}$ day.

\section{Discussion}

Some mechanisms have been previously proposed to explain the diarrheal effect of castor oil including inhibition of intestinal $\mathrm{Na}^{+}, \mathrm{K}^{+}$- ATPase activity to reduce normal fluid absorption (Nell and Rummel, 1984), activation of adenylate cyclase or mucosal cAMP mediated active secretion (Capasso et al., 1994) stimulation of prostaglandin formation (Galvez et al., 1993) platelet activating factor and recently nitric oxide has been claimed to contribute to the diarrheal effect of castor oil (Mascola et al., 1996). However, it is well evident that castor oil produces diarrhea due to its most active component recinoleic acid which causes irritation and inflammation of the intestinal mucosa, leading to release of prostaglandins, which results in stimulation of secretion (Gaginella et al., 1975). Since the methanol extract of the leaves of $W$. arborea successfully inhibited the castor oil-induced diarrhoea, the extract might have exerted its antidiarrheal action via antisecretory 
mechanism which was also evident from the reduction of total number of wet feces in the test groups in the experiment.

Alloxan is the most frequently employed agent for the induction of experimental diabetic animal models of human insulin-dependent diabetes mellitus. There is escalating evidence that alloxan causes diabetes by rapid exhaustion of a cells, by DNA alkylation and gathering of cytotoxic free radicals that is suggested to result from initial islet inflammation, followed by infiltration of activated macrophages and lymphocyte in the inflammatory focus. It leads to a fall in insulin release leading to stable hyperglycemic states (Yasodha et al., 2008).

The research on antidiabetic activity in alloxanised rats, aministration of methanol extract of $W$. arborea at 150 and $300 \mathrm{mg} / \mathrm{kg}$ body weight administered for 7 days was able to correct this anomaly significantly $(p<0.001)$. Significant reduction of blood glucose was observed from the $7^{\text {th }}$ day of the study. The comparable effect of the experimental extract with Metformin $\mathrm{HCl}$ may suggest similar mode of action since alloxan permanantly destroys the pancreatic ß-cells and the extract lowered blood sugar level in alloxanised rats, indicating that the extract possesses extra pancreatic effect. On the progression of treatment with methanol extract of $W$. arborea (150 and $300 \mathrm{mgkg}^{-1} \mathrm{day}^{-1)}$ fasting blood glucose level reduced to $6.01 \pm 0.57 \mathrm{mmol} / \mathrm{l}$ and $5.01 \pm 0.84 \mathrm{mmol} / \mathrm{l}$, respectively on $7^{\text {th }}$ day. These observations suggest that the extract might acquire insulin like effect on peripheral tissues either by promoting glucose consumption metabolism or inhibiting hepatic gluconeogenesis since alloxan treatment causes permanent destruction of ß-cells (Pari and Vankateswaram, 2002).

As fewer works have been conducted on this plant, next aim will be an attempt to isolate compounds responsible for these bioactivities.

\section{Acknowledgement}

The authors wish to thank to the Department of Pharmacy, BRAC University, Dhaka, Bangladesh, for providing laboratory facilities to carry out this research work.

\section{References}

Allen, S.J., Okoko, B., Martinez, E., Gregorio, G. and Dans, L.F. 2003. Probiotics for treating infectious diarrhoea. Coch. Datab. Syst. Rev. 4, Art. No.: CD003048.pub2. DOI:10.1002/14651858.CD003048.pub2.

Capasso, F., Mascolo, N., Izzo, A.A. and Gaginella, T.S. 1994. Dissociation of castor oil induced diarrhea and intestinal mucosal injury in rat: effect of NG-nitro-L-arginine methyl ester. Br. J. Pharmacol. 113, 1127-1130.

Cowan, M,M. 1999. Plant products as antimicrobial agents. Clin. Microbiol. Rev. 12, 564-582.

Dahanukar, S.A., Kulkarni, R.A., and Rege, N.N. 2000. Pharmacology of medicinal plants and natural Products. Ind. J. Pharmcol. 32, S81-S118.

FlowersofIndia.net [homepage on internet].India. 2009. Aviliable from http://www.flowersofindia.net/catalog/slides/Woolly Dyeing Rosebay.html.

Gaginella, T.S., Stewart, J.J., Olsen, W.A., and Bass, P. 1975. Action of recinoleic acid and structurally related fatty acid on the gastrointestinal tract. II. Effect on water and electrolyte absorption in vitro. J. Pharmacol. Exp. Ther. 195, 355-356.

Galvez, A., Zarzuelo, M.E., Crespo, M.D., Lorente, M., Ocete, A., and Jimenez, J. 1993. Antidiarrhoeic activity of Euphorbia hirta extract and isolation of active flavonoid constituents. Planta Med. 59,333-336.

Ghosh, R., Sharatchandra, K.H., Rita, S., and Thokchom, I.S. 2004. Hypoglycemic activity of Ficus hispida (bark) in normal and diabetic albino rats. Ind. J. Pharmacol. 36, 222225.

Lorke, D.A. 1983. A new approach to practical acute toxicity testing. Arch. Toxicol. 54, 275-287.

Mascolo, N., Izzo, A.A., Gaginella, T.S., and Capasso, F. 1996. Relationship between nitric oxide and platelet activating factor in castor oil induced mucosal injury in the rat duodenum. Arch. Pharmacol . 353, 680-684.

Mead, P.S., Slutsker, L., Dietz, V., McCaig, L.F., Bresee, J.S., Shapiro, C., Griffin, P.M. and Tauxe, R.V. 1999. Food related illness and death in the United States. Emerg. Infect. Dis. 5, 607-625.

Mpbd.info [Home page on the internet].Dhaka, Bangladesh. 2009. Aviliable from http://www.mpbd.info/plants/ wrightia-arborea.php\#.UAE- Z_Un_IU

Ngan, P.T. 1965. A revision of the genus Wrigthia (Apocynaceae). Annals of Missouri Botanical Garden. 52, 114-175

Nahar, L., Ripa, F.A., Zulfiker, A.H.M., Rokonuzzaman, M., Haque, M., and Islam, K.M.S. 2010. Comparative study of antidiabetic effect of Abroma augusta and Syzygium cumini on alloxan induced diabetic rat. Agric. Biol. J. N. Am. 1, 1268-1272. 
Nell, G., and Rummel, W. 1984. Action mechanism of secretagogue drugs. In: Csaky TZ (Ed.). Pharmacology of Intestinal Permeation, $2^{\text {nd }}$ ed. Berlin; Springer.

Oi, H., Matsuura, D., Miyake, M., Ueno, M.,Tukai, I., Yamamota, T., Kubo, M., Moss, J., and Noda, M. 2002. Identification in traditional herbal medications and confirmation by synthesis of factors that inhibit cholera toxin-induced fluid accumulation. Proc. Natl. Acad. Sci. 99, 3042-3046.

Pari, L. and Uma, M.J. 1999. Hypoglycemic effect of Musa sapientum L. in alloxan-induced diabetic rats. $J$. Ethnopharmacol. 68, 321-325.
Pari, L. and Venkateswaran, S. 2002. Hypoglycaemic activity of Scoparia dulcis L. extract in alloxan induced hyperglycaemic rats. Phytother. Res. 16, 662-664.

Piedrola,. G., Novo, E., Escober, F., and Garcia-Robles, R. 2001. White blood cell count and insulin resistance in patients with coronary artery disease. Ann. Endocrinol. 62, 7-10.

Takahashi, K., Matsuda, M., Ohashi, K., Taniguchi, K., Nakagomi, O., Abe, Y., and Mori, S. 2001. Analysis of antirotavirus activity of extract from Stevia rebaudiana. Antiviral. Res. 49, 15-24.

Yasodha., Krishna., Janapati., Jayaveera, K.N., Ravindra., Reddy, K., Rupesh, K., Raghavendra, D., and Siddaiah, M. 2008. J. Pharma. Chem.156-160. 